\title{
Decadal Distribution and Abundance Trends for the Late Stage Copepodites of Pseudocalanus spp. (Copepoda: Calanoida) in the US Northeast Continental Shelf Ecosystem.
}

\author{
Joseph Kane \\ National Marine Fisheries Service, NOAA, \\ 28 Tarzwell Drive, Narragansett, Rhode Island USA \\ Phone: 401-782-3244; Fax 401-782-3201; Email: joe.kane@noaa.gov
}

\begin{abstract}
Kane, J. 2014. Decadal Distribution and Abundance Trends for the Late Stage Copepodites of Pseudocalanus spp. (Copepoda: Calanoida) in the U.S. Northeast Continental Shelf Ecosystem. J. Northw. Atl. Fish. Sci., 46: 1-13. doi:10.2960/J.v46.m695
\end{abstract}

\begin{abstract}
The average annual cycle of abundance and the bimonthly distributions of the copepod Pseudocalanus spp. are described for U.S. Northeast continental shelf waters from samples collected on broad-scale plankton surveys 1977-2012. Population levels begin to increase during January-February, surge in March-April, and peak throughout the region during May-June. The copepod's population density declines sharply after June and becomes minimal from September-December. Spatially, seasonal high levels persist throughout the year in coastal waters surrounding and adjacent to the Cape Cod peninsula. During late spring, dense concentrations are found in Gulf of Maine coastal waters and in a high abundance band that extends southwestward from Georges Bank into the northern half of Middle Atlantic Bight waters. Pseudocalanus spp. interannual abundance variability was substantial; displaying several extended low and high periods through the time series. In general, numbers were high from the late 1970s through the early 1980s, low in the mid-1980s, elevated in the 1990s, and low again in the 2000s. This pattern was correlated negatively with temperature and positively with phytoplankton abundance trends. It is proposed that the copepods low abundance in the 2000s may have been caused by warmer temperatures that indirectly depressed the abundance of phytoplankton that this copepod uses for food. Survey data also indicate that predation pressure from salps and perhaps some additional species may contribute to the precipitous summer decline of Pseudocalanus spp. The copepod's abundance was found to be independent from the climatic variation associated with either the North Atlantic or Arctic Oscillation.
\end{abstract}

Keywords: Pseudocalanus spp., abundance, distribution, temperature, phytoplankton

\section{Introduction}

The waters of the U.S. Northeast Shelf Ecosystem extends from the Gulf of Maine south to Cape Hatteras, encompassing $260,000 \mathrm{~km}^{2}$ that form one of the most productive regions of the world's oceans. The ecosystem has supported large commercial fisheries for nearly four centuries, and contributes at least one billion dollars annually to the economies of the adjacent coastal states (Sherman et al., 1996). However, the region has been impacted by substantial environmental and anthropogenic perturbations in recent years, resulting in fundamental changes to ecosystem structure and function that now threaten the sustainability of the region's fish stocks (Ecosystem Assessment Program, 2009).
It has long been recognized that the year-class strength of important commercial fish species is affected by environmental conditions during their early life stages. Given that many fish larvae and juveniles feed on zooplankton, it is logical to hypothesize that there must be a relationship between zooplankton abundance and the size of future fish stocks. However, time series correlations between measures of plankton and recruitment have not been well established in marine ecosystems. It is generally believed these relationships are masked or confounded by the interaction of complex physical and biological processes that operate on different spatial and temporal scales (Heath and Lough, 2007). Nonetheless, recent studies in the Gulf of Maine and Georges Bank regions have begun to utilize lengthening time series 
to link fish recruitment with variations in zooplankton abundance (Pershing et al., 2005; Mountain and Kane, 2010; Friedland et al., 2013)

Pseudocalanus is a genus of small calanoid copepods that often dominate plankton samples collected in neretic waters of the Northern Hemisphere (Corkett and McLaren, 1978). Since their production cycle coincides with the spring bloom of diatoms, they are usually classified as winter-spring species in the Northwest Atlantic (Davis, 1987). There is a large body of literature showing that the different species of Pseudocalanus are the predominant prey item of many species of larval fish found in northern waters (e.g. Kane, 1984, Buckley and Durbin, 2006, Heath and Lough, 2007). A modeling study suggested that the apparent preference of early larvae for this copepod was caused by its high density and inherent behavioral traits that enhance detection by larval predators (Kristiansen et al., 2009). As fish larvae become older, they actively select for Pseudocalanus spp., preying especially on eggcarrying females as a means to maximize energy intake per attack (Robert et al., 2011). These findings all suggest that the abundance variability of this copepod is a critical factor determining the recruitment success of fish species found in such ecosystems.

Stegert et al. (2010) forecast that if the ocean continues to warm at its current pace, Pseudocalanus spp. will be less abundant in the North Atlantic. Their model predicts that climate induced changes will shorten the seasonal extent of the copepod's growth cycle and reduce its spatial distribution, affecting the food supply and the recruitment success of the region's fish stocks. NOAA Fisheries has monitored the zooplankton component of the U.S. Northeast Shelf Ecosystem with broadscale surveys that have collected plankton and hydrographic samples since the late 1970s. This paper utilizes this extensive data set to describe the average distribution and abundance patterns of Pseudocalanus spp. during the years 1977-2012. Interannual abundance variability is examined to determine if the current warming trend has already impacted the copepods life history. In addition, to gain insights into factors controlling the copepod's abundance, its variability was compared with year-to-year fluctuations in temperature, salinity, phytoplankton, and regional climatic indices.

\section{Materials and Methods}

\section{Plankton Data}

Bimonthly plankton sampling in the Northeast Continental Shelf Ecosystem (Fig. 1) was initiated in 1977 as part of the NOAA Fisheries MARMAP program (Sherman, 1980) and continues today as the ECOMON program (Hare and
Kane, 2012). All samples were collected with a $0.333 \mathrm{~mm}$ mesh net fitted on one side of a $61 \mathrm{~cm}$ bongo frame that was equipped with a calibrated flowmeter and towed at approximately 1.5 knots. Cruise tracks and detailed sampling procedures for plankton and other measurements on surveys before 1988 were summarized by Sibunka and Silverman $(1984,1989)$. The only major change in sampling methodology after 1987 was attaching a CTD instrument above the bongo frame to monitor the tow profile and collect simultaneous oceanographic data. The different survey sampling schemes employed during the time series have been described by Kane (2003).

In the laboratory, samples were reduced to approximately 500 organisms by subsampling with a modified box splitter. Zooplankton in the aliquot was identified to the lowest possible taxa and counted at the Plankton Sorting Center, Szczecin, Poland. The abundance of Pseudocalanus spp. is expressed here as numbers/100 $\mathrm{m}^{3}$ and includes only adults and copepodite stage five. Younger copepodite stages found in the samples were excluded because $0.333 \mathrm{~mm}$ mesh nets undersample other copepods of similar size (Anderson and Warren, 1991).

It is important to note that the data presented here do not represent a single species. Molecular genetics have distinguished two congeners within the surveyed waters: Pseudocalanus moultoni and Pseudocalanus newmani (Bucklin et. al, 1998). The two species are so similar morphologically that taxonomists are unable to readily distinguish between them. Therefore, all specimens were identified and counted as Pseudocalanus spp. Though it has been reported that there are some distribution differences between them, both species have similar monthly mean abundance values and frequently cooccur in samples from these waters (McGillicuddy and Bucklin, 2002). Thus, any bias introduced into this study by different proportions of these species is likely minimal.

The annual abundance cycles of copepod invertebrate predators captured in survey nets were examined to determine which ones would be mostly likely to cause the seasonal decline of Pseudocalanus spp. Five predators were chosen for analysis based on their high abundance just before or during the copepod's seasonal decline: the omnivorous copepods Centropages typicus and Centropages hamatus, chaetognaths, salps, and siphonophores. If the interannual variability of the potential predators were negatively correlated with Pseudocalanus spp. trends, then top-down control from them could be inferred.

Phytoplankton data were collected concurrently with a Continuous Plankton Recorder (CPR) towed at about $10 \mathrm{~m}$ depth along two transects that crossed 
the ecosystem (Fig. 1). Surveys were conducted at approximately monthly intervals across the Gulf of Maine and from off the coast of New York City southeastward towards Bermuda. The time series (1977-2009) of total phytoplankton counts, diatoms, and dinoflagellates from shelf waters were compared with the annual patterns of Pseudocalanus spp. abundance. The methods used on the CPR surveys along these two routes have been described by Jossi and Benway (2003).

\section{Environmental Data}

Temperature and salinity measurements were made routinely on all broad scale surveys. Surface temperature measurements from 1977-1999 were made with a stem thermometer from a surface bucket sample or were recorded via a thermistor attached to the vessel. From 2000 onward, temperature was measured with a CTD instrument. Samples for bottom temperature, surface salinity, and bottom salinity were collected with Niskin bottles from 1977 to 1986 , while later years utilized the CTD.

Climate variability was indexed with the winter phase of the North Atlantic Oscillation (NAO) and the Arctic Oscillation (AO), the Gulf Stream North Wall Index (GSI), and the Atlantic Multidecadal Oscillation (AMO). The NAO is an index which is based on the difference of

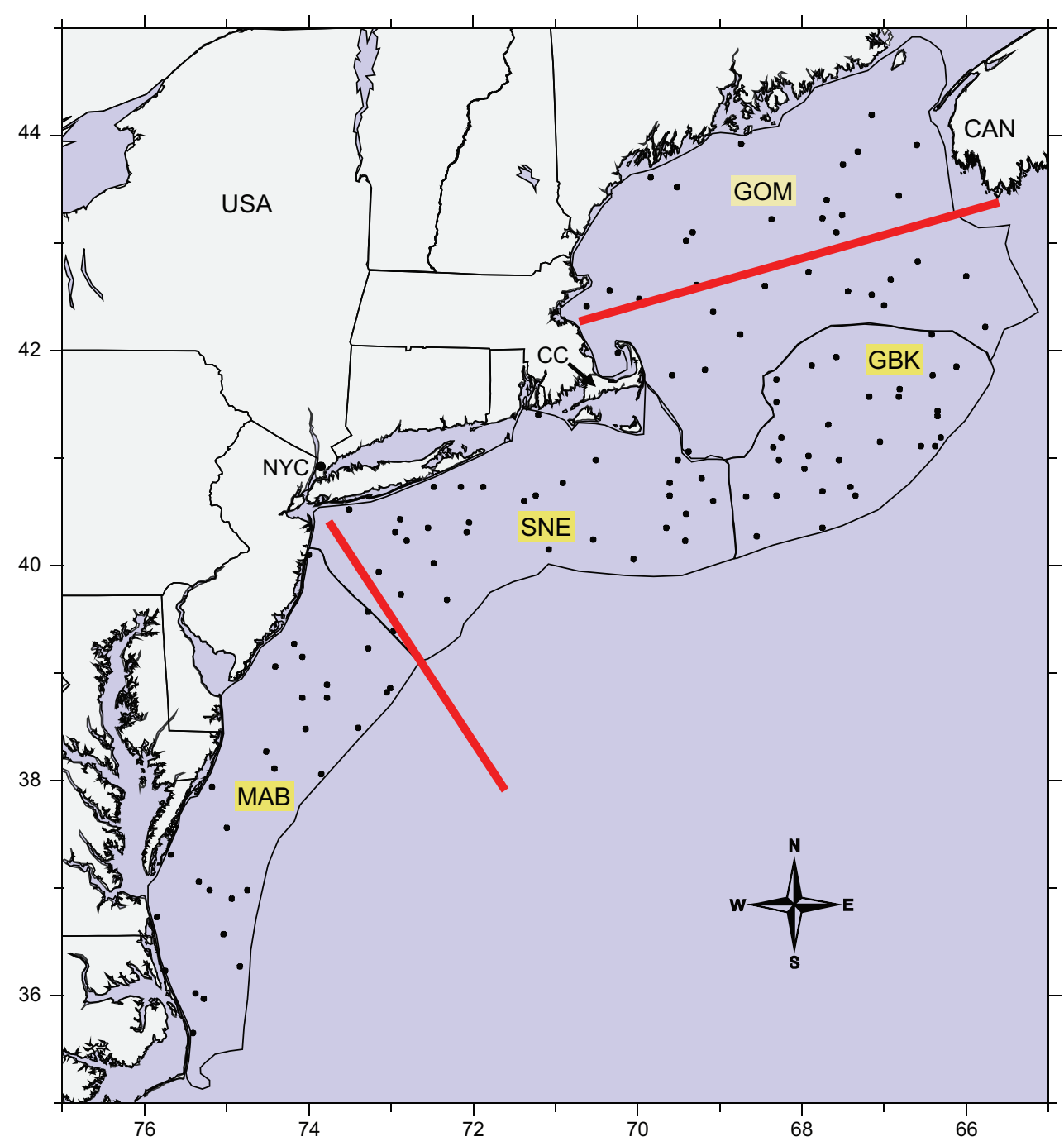

Fig. 1. Orientation map of area sampled during broad scale plankton surveys of the U.S. Northeast Shelf ecosystem. The survey area was divided into four subareas: 1) Gulf of Maine (GOM), 2) Georges Bank (GBK), 3) Southern New England (SNE), and 4) Middle Atlantic Bight (MAB). Markers on the map indicate the location of stations occupied during the 2009 May-June survey. The horizontal red lines are the approximate location of the CPR transects. Place name abbreviations: $\mathrm{NYC}=\mathrm{New}$ York City, $\mathrm{CC}=\mathrm{Cape}$ Cod. 
normalized sea level pressures between Lisbon, Portugal and Stykkisholmur/Reykjavik, Iceland from the months of December through March (Hurrell, 1995; data retrieved from: https://climatedataguide.ucar.edu/climate-data/ hurrell-north-atlantic-oscillation-nao-index-stationbased). The AO is a climate index of the state of the atmospheric circulation over the Arctic that indicates if polar air is locked in place or if it is allowed to penetrate south into middle latitudes (Thompson and Wallace, 1998; data retrieved from: http://www.cpc.ncep.noaa.gov/ products/precip/CWlink/daily_ao_index/JFM_season_ ao_index.shtml). The GSI is a measure of the position of the north wall of the Gulf Stream as it diverges from the North American coastline (Taylor, 1995; data retrieved from: http://www.pml-gulfstream.org.uk/Web2013.pdf). The AMO is a mode of natural variability occurring in the North Atlantic that is primarily associated with long duration changes in sea surface temperature (Kerr, 2000; data retrieved from: http://www.esrl.noaa.gov/psd/data/ correlation/amon.sm.data). These four indices of climate variability are all known to affect physical and biological measurements across the North Atlantic.

Analysis of the copepod's abundance variability was facilitated by dividing the ecosystem into four subareas whose boundaries are defined by oceanographic characteristics (Ingham et al., 1982): the Gulf of Maine (GOM), Georges Bank (GBK), Southern New England (SNE), and the Middle Atlantic Bight (MAB) (Fig. 1). Interannual variability was examined by calculating yearly anomalies for each variable within each region. To reduce the bias caused by sampling variability and to allow comparison between years, the average annual cycle of each variable was computed by fitting a spline curve function to the time series $\log 10(\mathrm{n}+1)$ transformed bimonthly or monthly (CPR data) mean values. This generates the expected value on any day of the year. Survey means were then subtracted from the projected values on the median day of that particular cruise. Anomalies from the seasonal cycle were then averaged over each year to produce an annual index. Sampling was too infrequent on broad scale surveys to calculate the annual anomaly in the GOM for the years 1989 and 1990 , in the SNE region for 1989, and in the MAB from 1989-1994.

Spearman's rank correlation analysis of annual anomalies was used to show connections between and among zooplankton and environmental variables. Autocorrelation in the data was accounted for by adjusting the effective degrees of freedom $\left(N^{*}\right)$ of each test using the following procedure (Pyper and Peterman, 1998):

$$
\frac{1}{N^{*}}=\frac{1}{N}+\frac{2}{N} \sum_{j}^{N / 5} r_{x x}(j) r_{y y}(j)
$$

where $N$ is the number of sample pairs,

and $r_{x x}(j)$ and $r_{v y}(j)$ are the sample autocorrelation of $\mathrm{x}$ and $\mathrm{y}$ at lag $\mathrm{j}$ (Box and Jenkins, 1976). The probability of rejecting a true null hypothesis was set low (0.01) to ameliorate the effects of multiple hypothesis tests. Abundance anomalies were also correlated with one, two, and three year lag periods of climatic indices to determine whether conditions in preceding years affect the copepods productivity.

Contoured bimonthly and seasonal distribution maps of abundance were generated using the Surfer 9 software package (Golden Software) to interpolate abundance surfaces with kriging gridding methods at default settings.

\section{Results}

\section{Distribution and Abundance}

The annual abundance cycle of Pseudocalanus spp. is similar throughout the study regions. The population begins to increase during winter from its annual low, surges upward in March-April, and reaches its annual maximum in May-June (Fig. 2). Mean abundance declines sharply after June and is minimal from September through December. The copepod's highest May-June abundance is usually measured in the SNE subarea, while the lowest

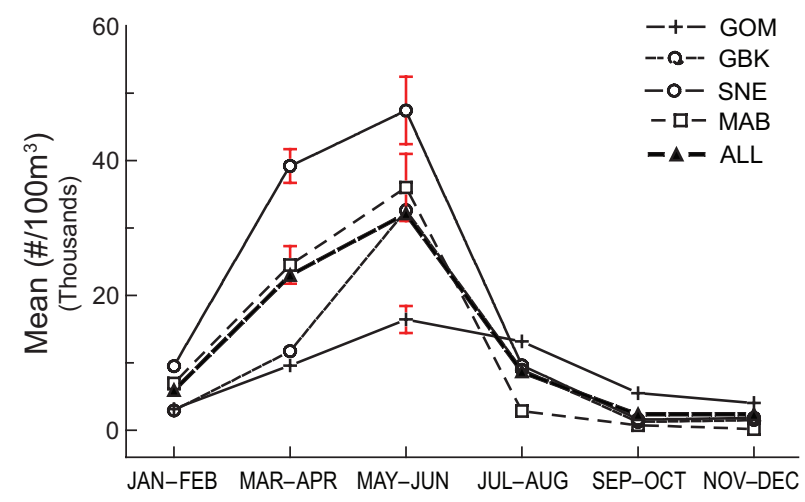

Fig. 2. The time series annual mean abundance cycle of Pseudocalanus spp. in the U.S. Northeast Shelf ecosystem and in each of its four subareas. Markers are the mean of annual means from samples collected in the bimonthly periods. Isolated points during the spring season have error bars to indicate the $95 \%$ confidence interval of the mean. 
is found in the GOM. However, the summer decline is comparatively moderate in the latter region, elevating GOM mean abundance above all other regions during the second half of the year (Fig. 2).

The pattern of the copepods abundance cycle was persistent throughout the time series on GBK, but displayed decadal variability in other surveyed regions (Fig. 3). Peak abundance was delayed in the GOM until July-August during the 1980s (Fig. 3A) and occurred earlier (March-April) in SNE waters during the 1990s (Fig. 3C). These were only temporary shifts; both regions had the time series mean pattern return in the following decade. However, the Pseudocalanus spp. spring maximum may have permanently shifted in MAB waters. During the late 1970s and 1980s peak abundance was usually recorded there in March-April, while in the 1990s and 2000s it was measured two months later during May-June (Fig. 3D). This delay caused a marked reduction in the copepods early spring abundance during the 2000s (Fig. 3D).

Spatially, Pseudocalanus spp. is usually found year round, except in the southernmost tip of the region during November-December (Fig. 4). There is always present a year-round band of elevated abundance that extends from GOM coastal waters, around Cape Cod, and across Nantucket shoals. A pocket of high abundance off the southwestern coast of Nova Scotia also persists throughout the year. The abundance of Pseudocalanus spp. is usually higher in the shallower areas $(<100 \mathrm{~m})$ of the ecosystem (Fig. 4).

The perennial high abundance region of Pseudocalanus spp. expands during winter, reaching across GBK and into SNE coastal waters (Fig. 4). In early spring this region enlarges along coastal waters and expands into offshore waters. During the late spring maximum, high concentrations are found in GOM coastal waters and in a large belt that extends from GBK southwestward across SNE and into MAB waters. The band constricts sharply in summer and by early fall is confined to GOM coastal waters. Pseudocalanus spp. becomes very sparse in MAB waters during the autumn months (Fig. 4).

Distribution patterns were relatively stable through the time series with no major poleward or longitudinal shifts (data not shown). However, contrasting seasonal abundance levels through the decades reinforced the changing spring pattern described earlier for the MAB region. New time divisions used to pinpoint changes for early spring distributions revealed that the high abundance

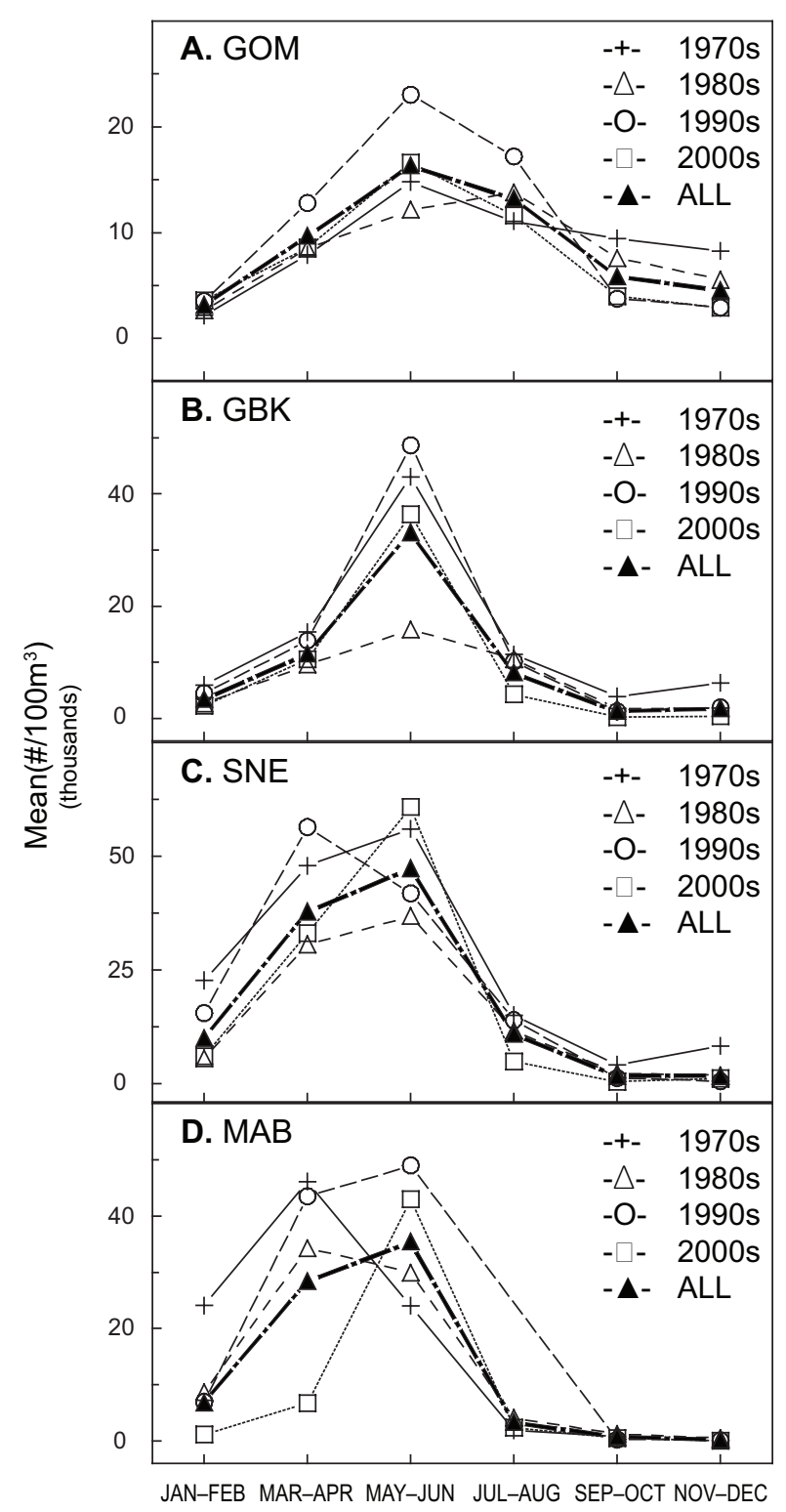

Fig. 3. The decadal annual abundance cycles of Pseudocalanus spp. in the A) GOM (Gulf of Maine), B) GBK (Georges Bank), C) SNE (Southern New England), and D) MAB (Mid-Atlantic Bight) regions.

that extended into the region during the first half of the time series began to withdraw northward during the late 1990s (Fig. 5). The band disappeared entirely after 2005 (Fig. 5), depressing mean abundance levels there to its time series low (Fig. 3D).

Pseudocalanus spp. interannual abundance exhibited two high and low multi-year abundance periods that 

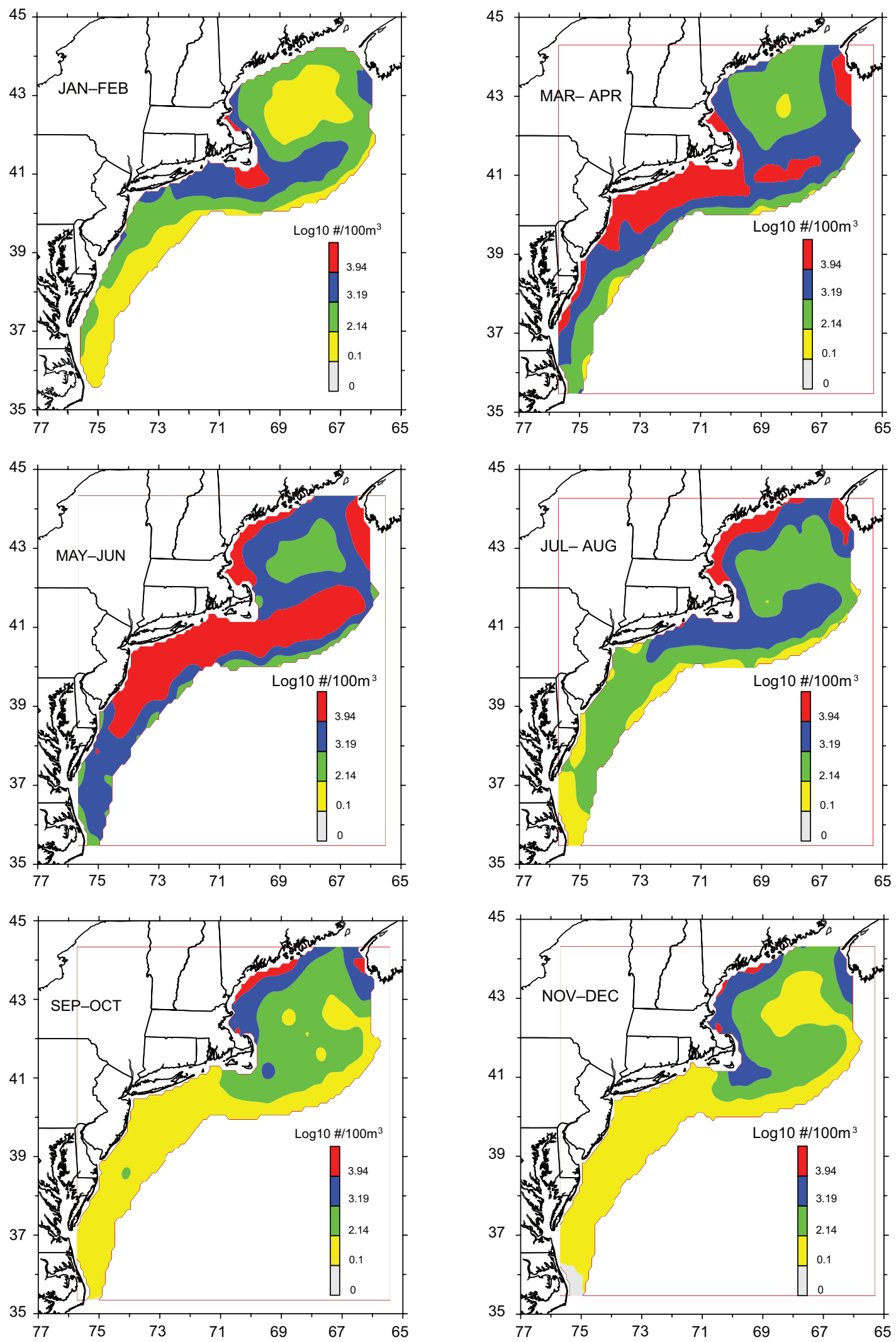

Fig. 4. Bimonthly composite distribution and abundance of Pseudocalanus spp. in the U.S. Northeast Shelf ecosystem. 
were present throughout most of the ecosystem (Fig. 6). In general, abundance was high from the late $1970 \mathrm{~s}$ through the early 1980s, low in the mid 1980s, elevated during the 1990s, and below average during the 2000s. This rollercoaster pattern was more distinct in the two more northern regions, while annual indices were more variable in the southern half of the ecosystem. The lowest
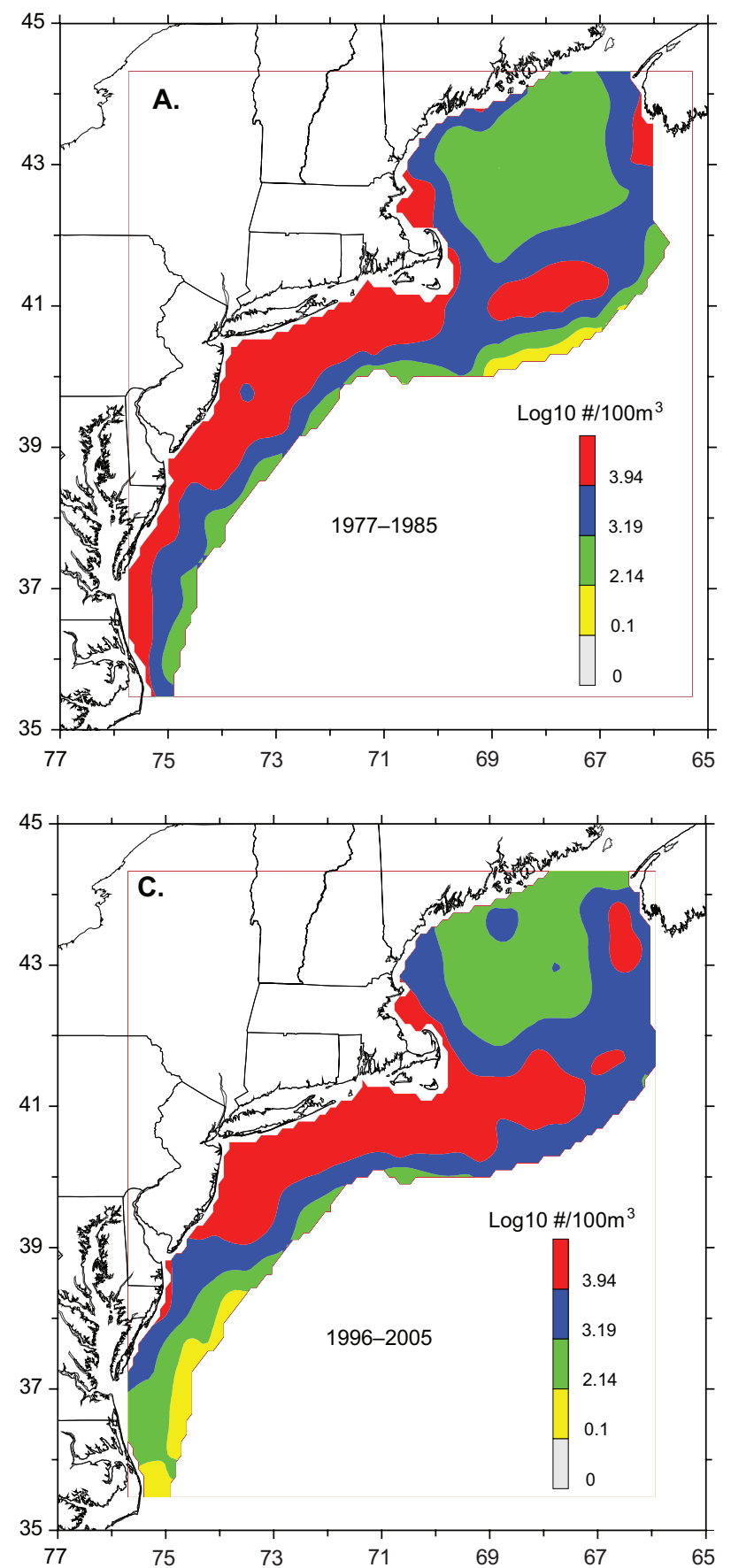

abundance levels of the time series were recorded during the 2000s in all regions (Fig. 6).

\section{Predation}

Salps were found to be the most likely of the potential predators examined that have applied top-down pressure
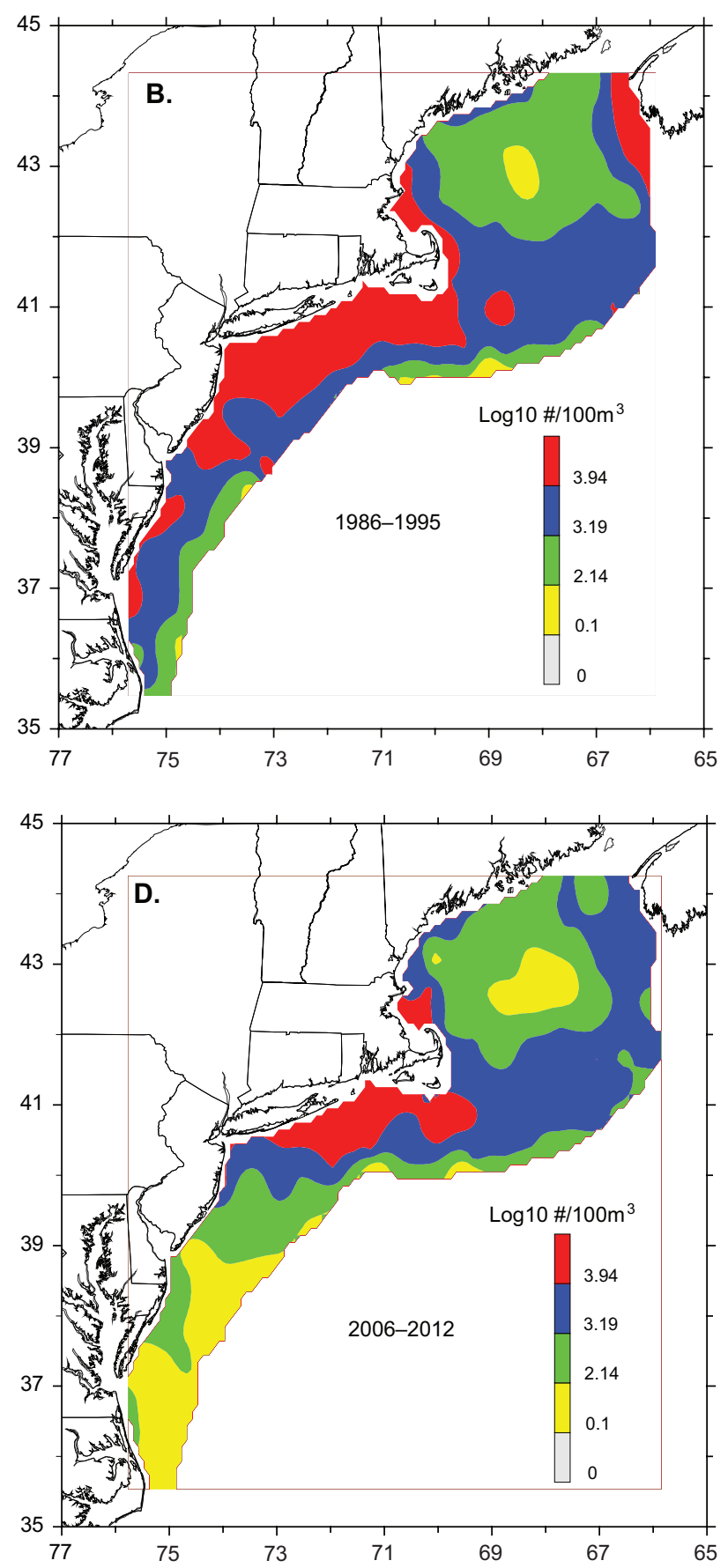

Fig. 5. Average early spring (March-April) distribution and abundance of Pseudocalanus spp. in the U.S. Northeast Shelf ecosystem during A) 1977-1985, B) 1986-1995, C) 1996-2005, and D) 2006-2012. 
on the population levels of Pseudocalanus spp. Annual abundance trends of both taxa were negatively correlated throughout the ecosystem. Though their overall abundance is low on GBK (Fig. 7), there was a significant negative $(p<0.01)$ relationship measured there and substantial $(p<0.10)$ ones found in the SNE and MAB regions (Table 1). Salp abundance explodes throughout most of the ecosystem during the summer months when Pseudocalanus spp. numbers diminish (Fig. 7). These gelatinous organisms are common members of the zooplankton community during summer, dispersed throughout the shelf in an increasing north to south abundance gradient (Fig. 7).

Pseudocalanus spp. trends were also negatively correlated with both siphonophore and chaetognath abundance in the southern half of the ecosystem (Table 1). Though coefficients were moderate, in certain years these predators likely reduce the copepods abundance there. There was no evidence found that the omnivorous copepods Centropages typicus and Centropages hamatus affect the density of Pseudocalanus spp., correlations between annual abundance levels were positive throughout the ecosystem (Table 1).

\section{Correlation Analysis}

Annual trends of Pseudocalanus spp. abundance in all regions were negatively correlated with temperature and salinity measurements, with nearly half of them found to be significant $(p<0.01)$ (Table 2$)$. The highest correlations were found in the SNE region with surface and bottom temperature measurements (Table 2). Annual temperature anomalies in this region have been highly variable over the time series, but have been trending upward in recent years (Fig. 8A), as opposed to the downward trend observed for Pseudocalanus spp. abundance (Fig. 6C).

Climatic indices were also all negatively correlated with Pseudocalanus spp. annual abundance anomalies (Table 2). The relationship was significant for the AMO
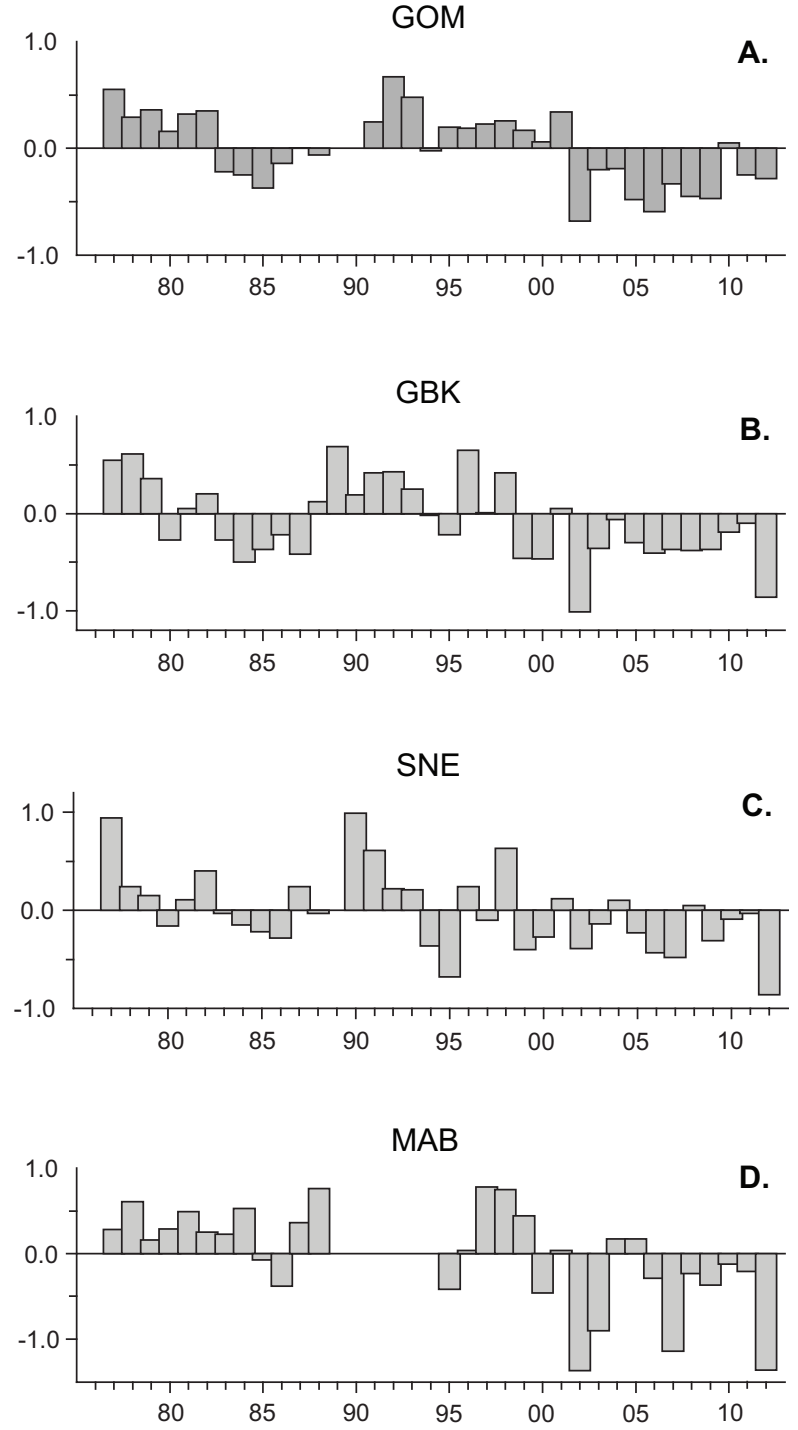

Fig. 6. Annual anomalies (1977-2012) of Pseudocalanus spp. abundance in the A) GOM (Gulf of Maine), B) GBK (Georges Bank), C) SNE (Southern New England), and D) MAB (Mid-Atlantic Bight) regions. Each bar represents the annual mean of survey log abundance anomalies.

Table 1: Spearman correlation coefficients between the regional annual abundance anomalies of Pseudocalanus spp. and taxa that are potential predators of the copepod. An asterisk placed after the coefficient indicates a significant $(p<0.01)$ relationship.

\begin{tabular}{lcccc}
\hline \hline Taxa & Gulf of Maine & Georges Bank & Southern New England & Middle Atlantic Bight \\
Centropages hamatus & 0.11 & 0.11 & 0.34 & 0.40 \\
Centropages typicus & $0.62 *$ & 0.19 & 0.07 & 0.16 \\
Salps & -0.08 & $-0.43 *$ & -0.29 & -0.33 \\
Siphonophores & 0.44 & -0.14 & -0.17 & -0.26 \\
Chaetognatha & $0.57^{*}$ & 0.06 & -0.25 & -0.33 \\
\hline
\end{tabular}


KANE: Distribution and Abundance Trends of Pseudocalanus spp. in the U.S. Northeast Continental Shelf Ecosystem.

Table 2: Spearman correlation coefficients between the regional annual anomalies of Pseudocalanus spp. abundance and environmental variables. An asterisk placed after the coefficient indicates a significant $(p<0.01)$ relationship.

\begin{tabular}{|c|c|c|c|c|}
\hline Variable & Gulf of Maine & Georges Bank & Southern New England & Middle Atlantic Bight \\
\hline North Atlantic Oscillation & -0.01 & -0.08 & -0.20 & -0.12 \\
\hline Arctic Oscillation & -0.07 & -0.10 & -0.20 & -0.28 \\
\hline Gulf Stream Index & -0.16 & -0.22 & -0.36 & $-0.51 *$ \\
\hline $\begin{array}{l}\text { Atlantic Multi- } \\
\text { Decadal Oscillation }\end{array}$ & -0.42 & $-0.40 *$ & -0.32 & -0.29 \\
\hline Surface Temperature & -0.29 & $-0.41 *$ & $-0.70^{*}$ & $-0.60 *$ \\
\hline Surface Salinity & -0.01 & -0.20 & -0.33 & $-0.57 *$ \\
\hline Bottom Temperature & $-0.46^{*}$ & $-0.41^{*}$ & $-0.69^{*}$ & $-0.47 *$ \\
\hline Bottom Salinity & -0.28 & -0.38 & -0.38 & $-0.57 *$ \\
\hline Total Phytoplankton & $0.71 *$ & - & 0.30 & $0.61 *$ \\
\hline Total Diatoms & $0.69^{*}$ & - & 0.01 & 0.21 \\
\hline Total Dinoflagellates & $0.57^{*}$ & - & 0.35 & $0.69^{*}$ \\
\hline
\end{tabular}

in GBK waters and for the GSI in the MAB region. Correlation coefficients with the NAO and AO indices were all low and insignificant (Table 2). Lagging the climatic indices by one to three years did not substantially change correlations or reveal meaningful relationships (data not shown).

Total counts of phytoplankton, diatoms, and dinoflagellates along the GOM CPR transect were strongly positively correlated $(p<0.01)$ with Pseudocalanus spp. abundance trends in the region (Table 2). Annual phytoplankton abundance anomalies there had sustained high and low periods (Fig. 8B), very similar to the copepod's yearly pattern (Fig. 6A). Total phytoplankton counts on the CPR transect that bisected the SNE and MAB regions were also positively correlated with Pseudocalanus spp. abundance in these regions. However, only relationships between total counts and the dinoflagellate fraction from the MAB were significant $(p<0.01)$ (Table 2$)$.

\section{Discussion}

The life cycle of Pseudocalanus spp. is the classic spring pattern found in temperate waters. The copepod's abundance increases sharply throughout the region during early spring and large populations are established in late spring. Numbers diminish during summer and are minimal through the autumn and winter months. Spatially, Pseudocalanus spp. is usually found in a decreasing inshore-offshore abundance gradient with high seasonal levels persisting throughout the year in coastal waters surrounding and adjacent to the Cape Cod peninsula.
The copepod's long term abundance trend displayed a roller coaster pattern, with high and low periods persisting for several years. Surface and bottom temperature readings collected on surveys were more variable, but annual indices of both measurements were found to be significantly negatively correlated to Pseudocalanus spp. patterns. This was largely driven by the low abundance measured in the 2000s, which coincides with the regions recent warming trend (Belkin, 2009). The copepods abundance was very low in 2012, when sea surface temperatures in shelf waters were the highest ever recorded (Mills et al., 2013).

Sea surface temperatures measured on our surveys during the $2000 \mathrm{~s}$ were on average $0.74^{\circ} \mathrm{C}$ higher then values recorded in the 1990s. The decline in Pseudocalanus spp. abundance is certainly associated with this warming trend, but it seems unlikely that this moderate increase in temperature would directly lower population levels. Pseudocalanus spp. can tolerate and thrive in a wide range of temperatures. On the U.S. Northeast Shelf, it was captured by the CPR at locations where temperatures ranged from $0.3-27.7^{\circ} \mathrm{C}$. Modeling studies and laboratory experiments with Pseudocalanus spp. indicate that population growth is positive in waters where temperatures are less than $20^{\circ} \mathrm{C}$ (e.g. McLaren, 1966; Corkett and Zillioux, 1975; Dzierzbicka-Glowacka, 2004; Stegert et al., 2010). This thermal adaptability has led investigators to hypothesize that the copepods summer decline is primarily caused by predation mortality, rather than the physiological effects of increasing temperatures (Davis, 1984; Ji et al., 2009). Therefore, it seems unlikely that the 

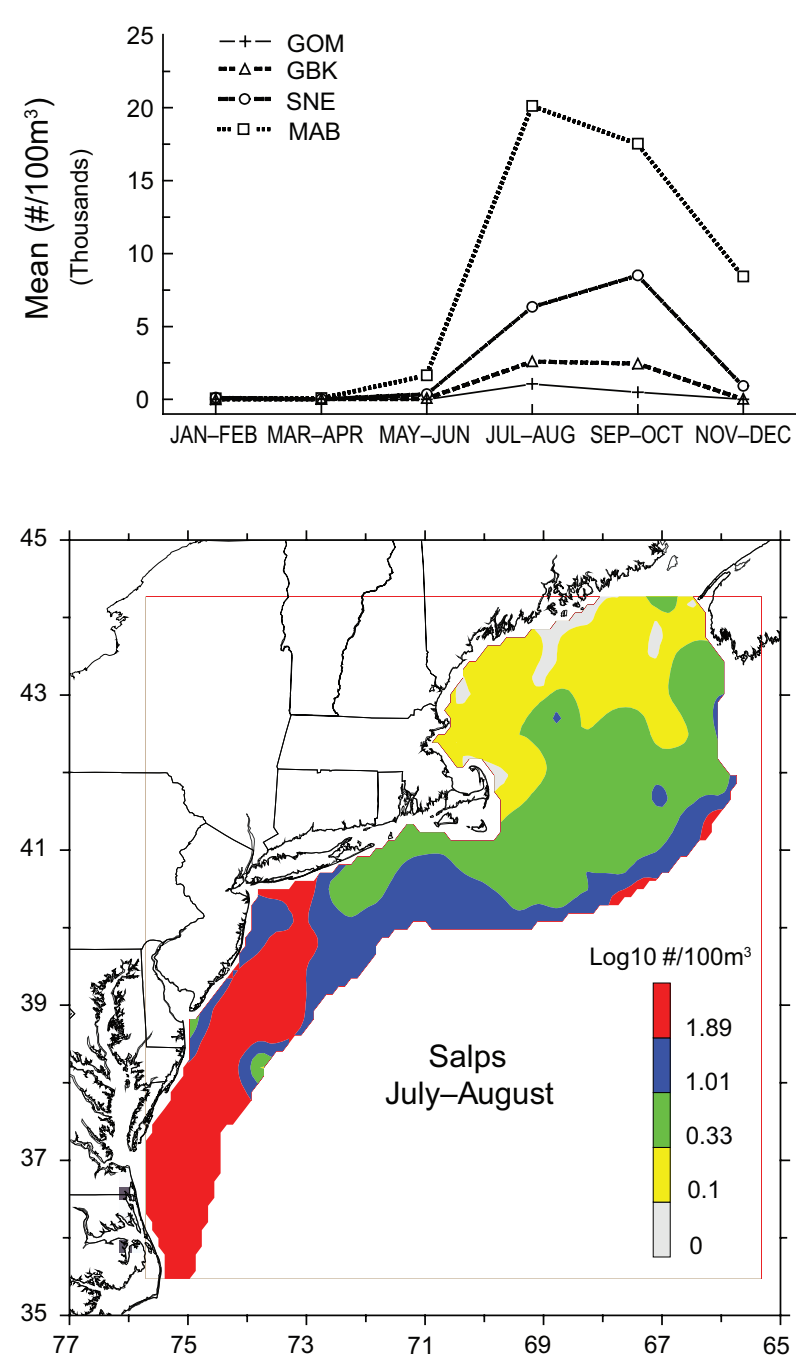

Fig. 7. Time series annual abundance cyle of salps in the four subareas of the U.S. Northeast Shelf ecosystem (upper panel) and their average July-August distribution (lower panel).

modest temperature increase in the 2000s directly lowered Pseudocalanus spp. population levels.

Phytoplankton abundance was the only variable examined that was positively correlated to the copepods interannual variability. Patterns of annual abundance anomalies for both measurements were strikingly similar in the GOM (Figs.6A, 8B). Previous studies in this region have linked changes in phytoplankton phenology and productivity to the copepod's surge in the 1990s (Pershing et al., 2005; Kane, 2007). Greene and Pershing (2007) proposed that this increased production in the lower trophic levels was caused by Arctic climate conditions that increased freshwater export into the North Atlantic that enhanced stratification and extended the phytoplankton growing season. However, additional observations in the 2000s found that reduced salinity did not always enhance zooplankton productivity (Hare and Kane, 2012). Correlation analysis of pre-2000 and post-2000 data subsets demonstrated that salinity was not a factor in the new decade. The decline of Pseudocalanus spp. and phytoplankton abundance was likely caused by conditions indirectly associated with the warmer temperatures measured in the 2000s. The increased temperatures would have accelerated phytoplankton growth and produced earlier blooms, perhaps shifting events out of phase with other elements that are needed for maximum production in the ecosystem. Warming would also increase stratification, which could play a major role limiting Pseudocalanus spp. production. Stratified waters impede the mixing of deep nutrient-rich waters into surface layers and suppress the availability of phytoplankton food stocks (Kamykowski and Zentara, 2005). New algorithms are currently being developed to provide a stratification time series to test this hypothesis. Warmer temperatures are also believed to be the cause of high precipitation and runoff in the GOM during the 2000s, which reduced light availability and lowered overall primary productivity (Balch et al., 2012). Though it is uncertain which or what combination of biological-physical processes depressed phytoplankton levels in the 2000s, the effects cascaded further up the food web.

A modeling study analyzing Pseudocalanus spp. populations in the GOM also found strong connections to bottom-up processes, but the data indicate that predation may also have a major role determining abundance levels (Ji et al., 2012). Out of all the predator groups sampled in our surveys, evidence was found that salps were the most likely to depress the copepod's population in summer. They are large, gelatinous zooplankton that grow rapidly and have been reported to form large swarms in the Northwest Atlantic Ocean during summer (Wiebe et al., 1979; Madin et al., 2006). Salps were the third most abundant $\left(16587 / 100 \mathrm{~m}^{3}\right)$ taxon captured in nets towed through MAB waters during July-August survey cruises. Though there is no record of salps directly feeding on Pseudocalanus spp., these filter feeders ingest a wide size range of particulate matter and can substantially reduce the quantities of phytoplankton, bacteria, and microzooplankton that other mesozooplankton use for food (Paffenhofer, 1994; Vargas and Madin, 2004, Bernard et al., 2012). Several studies have proposed that high predation rates by salps indirectly limit the growth of copepod populations (Dubischar and Bathmann, 1997; Halsband-Lenk et al., 2001; Everett et al., 2011). This study has found that salps and Pseudocalanus spp. population levels were tightly coupled during the time series, suggesting that salp predation is responsible for the copepod's sharp summer decline. However, since our surveys do not measure phytoplankton size structure, we 

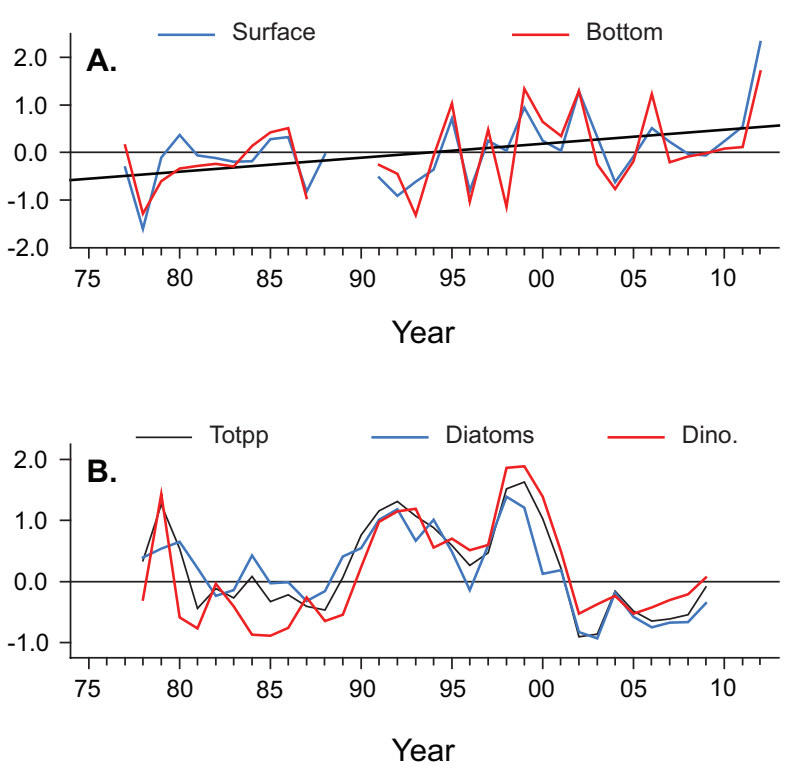

Fig. 8. A) Annual anomalies (1977-2012) of surface and bottom water temperatures $\left({ }^{\circ} \mathrm{C}\right)$ in the Southern New England region with values fit with a linear trend line. B) Annual abundance (\#m3) anomalies (1978-2009) of total phytoplankton (Totpp), diatoms, and dinoflagellates (Dino.) captured along the Gulf of Maine CPR transect.

could not test if the correlation was caused by factors that created feeding conditions favorable for salps and detrimental for Pseudocalanus spp. production.

During the past century, water temperature has been gradually rising in the North Atlantic Ocean (Beaugrand, 2009). If ocean temperatures continue to warm at rates predicted by general circulation models, it is projected that mortality of Pseudocalanus spp. will increase in warmer waters and substantially reduce population abundance in shelf areas south of $45^{\circ} \mathrm{N}$ (Stegert et al., 2010). Spatially, the authors predict that the copepods population center will shift northwards during the 21 st century. Have these transitions already begun in the southernmost region of the ecosystem? Distribution maps of Pseudocalanus spp. in March-April show that an area of high abundance present in the MAB region during the initial decade of sampling has been slowly retreating northward during the time series, drastically depressing seasonal mean abundance. One possibility may be that warmer summer temperatures have depressed the size of the overwintering population, reducing the following year's spring maximum. However, survey data do not support this hypothesis. Correlation analysis between abundance anomalies in autumn and spring of the following year produced coefficients that were low and insignificant. Thus far, it seems unlikely that the modest temperature increases in the 2000s directly affected MAB Pseudocalanus spp. production in early spring. The exact mechanism remains elusive, but it is probably related to the decadal low phytoplankton food stocks.

Global circulation models have projected that the earth will continue to warm under higher levels of greenhouse gases (IPCC, 2007). As ocean temperatures rise, recruitment success of higher trophic levels will be affected because it depends on the synchronization of primary and secondary production. For example, warming of the North Sea has already been correlated with changes in the zooplankton community, resulting in low food levels for cod larvae that have led to a decline in overall recruitment (Beaugrand et al., 2003). Evidence was found that adult cod stocks in the North Atlantic have been unable to rebuild because climate change has altered the distribution of temperatures, causing low levels of zooplankton prey for larval stages (Friedland et al., 2013). The present study has found that increasing temperatures in the 2000s has depressed phytoplankton food stocks and the abundance of the dominant copepod Pseudocalanus spp., a major prey item of larval fish.

Extending our time series into the future will be necessary to measure the response of lower trophic levels to the projected anthropogenic and natural oscillations that may impact the ecosystem. However, the exact mechanisms responsible for the observed patterns will be difficult to determine from our surveys which provide only bimonthly snap-shots of ecosystem conditions. Complex numerical models and dedicated process orientated studies will be needed to define the complex of factors that intertwine to determine how warming seas affect primary and secondary production. Understanding the effects of climate change on the transfer of resources through trophic levels will be central to predict future alterations to the ecosystem's food web.

\section{Acknowledgements}

I thank the numerous people who worked hard to collect and process the time series of zooplankton and environmental data used in this paper. Special thanks to Jon Hare and Clyde MacKenzie Jr. for providing constructive comments on early drafts of the manuscript.

\section{References}

ANDERSON, J. T., and W. G. WARREN. 1991. Comparison of catch rates among small and large bongo samplers for Calanus finmarchicus copepodite stages. Can. J. Fish. Aquat. Sci., 48: 303-308. http://dx.doi.org/10.1139/f91-042

BALCH, W. M., D. T. DRAPEAU, B. C. BOWLER, and T. G. HUNTINGTON. 2012. Step-changes in the physical, 
chemical and biological characteristics of the Gulf of Maine, as documented by the GNATS time series. Mar. Ecol. Prog. Ser., 450: 11-35. http://dx.doi.org/10.3354/ meps09555

BEAUGRAND, G. 2009. Decadal changes in climate and ecosystems in the North Atlantic Ocean and adjacent seas. Deep-Sea Res. II, 56: 656-673. http://dx.doi.org/10.1016/j. dsr2.2008.12.022

BEAUGRAND, G., K. M. BRANDER, J. A. LINDLEY, S. SOUISSI, and P. C. REID. 2003. Plankton effect on cod recruitment in the North Sea. Nature, 426: 661-664. http:// dx.doi.org/10.1038/nature02164

BELKIN, I. M. 2009. Rapid warming of Large Marine Ecosystems. Progr. Oceanogr., 81: 207-13. http:// dx.doi.org/10.1016/j.pocean.2009.04.015. http://dx.doi. org/10.1016/j.pocean.2009.04.011

BERNARD, K. S., D. K. STEINBERG and O. M. E. Schofield. 2012. Summertime grazing impact of the dominant macrozooplankton off the Western Antarctic Peninsula Deep-Sea Res. I, 62: 111-122.

BOX, G. E. P., and G. W. JENKINS. 1976. Time series analysis: forecasting and control. Holden-Day, San Francisco, CA.

BUCKLEY, L. F., and E. G. DURBIN. 2006. Seasonal and inter-annual trends in the zooplankton prey and growth rate of Atlantic cod (Gadus morhua) and haddock (Melanogrammus aelgefinus) larvae on Georges Bank. Deep-Sea Res. II, 53: 2758-2770. http://dx.doi. org/10.1016/j.dsr2.2006.08.009

BUCKLIN, A., A. M. BENTLEY and S. P. FRANZEN. 1998. Distribution and relative abundance of the copepods Pseudocalanus moultoni and P. newmani on Georges Bank based on molecular identification of sibling species. Mar. Biol., 132: 97-106. http://dx.doi.org/10.1007/ s002270050375

CORKETT, C. J., and I. A. MCLAREN. 1978. The biology of Pseudocalanus. Adv. Mar. Biol., 15: 1-231. http://dx.doi. org/10.1016/S0065-2881(08)60404-6

CORKETT, C. J., and E. J. ZILLIOUX. 1975. Studies on the effect of temperature on the egg laying of three species of calanoid copepods in the laboratory. Bull. Plankton Soc. Japan, 21: 13-21.

DAVIS, C. S. 1984. Predatory control of copepod seasonal cycles on Georges Bank. Mar. Biol., 82: 31-40. http://dx.doi. org/10.1007/BF00392761

1987. Zooplankton life cycles. In: Georges Bank. R. A. Bakus and D. W. Bourne (eds.) MIT Press, Cambridge, p. 256-267.

DUBISCHAR, C. D., and U. V. BATHMANN. 1997. Grazing impact of copepods and salps on phytoplankton in the Atlantic sector of the Southern ocean. Deep Sea Research II: Topical Studies in the Atlantic Sector of the Southern Ocean. 44: 415-433. http://dx.doi.org/10.1016/S09670645(96)00064-1

DZIERZBICKA-GLOWACKA, L. 2004. Growth and development of copepodite stages of Pseudocalanus spp. J. Plankton Res., 26: 49-60.

ECOSYSTEM ASSESSMENT PROGRAM. 2009. Ecosystem Assessment Report for the Northeast U.S. Continental Shelf
Large Marine Ecosystem. US Dept. Commer., Northeast Fish. Sci. Cent. Ref. Doc. 09-11: 1-34.

EVERETT, J. D., M. E. BAIRD, and I. M. SUTHERS. 2011. Three-dimensional structure of a swarm of the salp Thalia democratica within a cold-core eddy off southeast Australia. J. Geophys. Res., 116: C12046. http://dx.doi.org/10.1029/2011JC007310

FRIEDLAND, K., J. KANE, J. HARE, R. G. LOUGH, P. S. FRATANTONI, M. J. FOGERTY, and J. A. NYE. 2013. Thermal habitat constraints on zooplankton species associated with Atlantic cod (Gadus morhua) on the US Northeast Continental Shelf. Progr. Oceanogr., 116: 1- 13. http://dx.doi.org/10.1016/j.pocean.2013.05.011

GREENE, C. H., and A. J. PERSHING. 2007. Climate drives sea change. Science, 315: 1084-1085. http://dx.doi. org/10.1126/science. 1136495

HALSBAND-LENK,C., S. NIVAL, F. CARLOTTI, and H. J. HIRCHE. 2001. Seasonal cycles of egg production of two planktonic copepods, Centropages typicus and Temora stylifera, in the North-western Mediterranean Sea J. Plankton Res. 23: 597-609. http://dx.doi.org/10.1093/ plankt/23.6.597

HARE, J. A., and J. KANE. 2012. Zooplankton of the Gulf of Maine-a changing perspective. In: Advancing an Ecosystem Approach in the Gulf of Maine. Am. Fisheries Soc. Symposium. Stephenson, R., J. Annala, J. Runge, and M. Hall-Arber, (eds.)79: 115-137.

HEATH, M. R., and R. G. LOUGH. 2007. A synthesis of largescale patters in the planktonic prey of larval and juvenile cod (Gadus morhua). Fish. Oceanogr., 16: 169-185. http:// dx.doi.org/10.1111/j.1365-2419.2006.00423.x

HURRELL, J. W. 1995. Decadal trends in the North Atlantic Oscillation: Regional temperatures and precipitation. Science, 269: 676-679. http://dx.doi.org/10.1126/ science.269.5224.676

INGHAM, M. C., R. S. ARMSTRONG, J. L. CHAMBERLIN, et al. 1982. Summary of the Physical Oceanographic Processes and Features pertinent to Pollution Distribution in the Coastal and Offshore Waters of the Northeastern United States, Virginia to Maine. NOAA Tech. Mem., NMFS-F/ NEC-17 322 pp.

IPCC. 2007. Climate change 2007 - the physical science basis. In: Contribution of Working Group I to the Fourth Assessment Report of the IPCC. Solomon, S., D. Qin, M. Manning, Z. Chen, M. Marquis, K. B. Averyt, M. Tignor, and H. L Miller, (eds.), Cambridge University Press, Cambridge, UK, 996 pp.

J, R., C. S. DAVIS, C. S. CHEN, and R. C. BEARDSLEY. 2009. Life history traits and spatiotemporal distributional patterns of copepod populations in the Gulf of Maine-Georges Bank region. Mar. Ecol. Prog. Ser., 384: 187-205. http://dx.doi. org/10.3354/meps08032

JI, R., C. STEGERT, and C. S. DAVIS. 2012. Sensitivity of copepod populations to bottom-up and top-down forcing: a modeling study in the Gulf of Maine region J. Plankton Res., 25: 151-167.

JOSSI, J. W., and R. L. BENWAY. 2003. Variabilty of Temperature and Salinity in the Middle Atlantic Bight 
KANE: Distribution and Abundance Trends of Pseudocalanus spp. in the U.S. Northeast Continental Shelf Ecosystem.

and Gulf of Maine based on data collected as part of the MARMAP ships of Opportunity program, 1978-2001. NOAA Tech. Mem. NMFS-NE-172, 92 pp.

KAMYKOWSKI, D., and S. J. ZENTARA. 2005. Changes in world ocean nitrate availability through the $20^{\text {th }}$ century. Deep-Sea Res. I, 52: 1719-1744. http://dx.doi. org/10.1016/j.dsr.2005.04.007

KANE, J. 1984. The feeding habits of co-occurring cod and haddock larvae. Mar. Ecol. Prog. Ser., 16: 9-20. http:// dx.doi.org/10.3354/meps016009

2003. Spatial and temporal abundance patterns for late-stage copepodites of Metridia lucens (Copepoda: Calanoida). J. Plankton Res., 25: 151-167. http://dx.doi.org/10.1093/plankt/25.2.151 2007. Zooplankton Abundance trends on Georges Bank, 1977-2004. ICES J. Mar. Sci., 64: 909-919. http://dx.doi.org/10.1093/icesjms/fsm066

KERR, R. A. 2000. A North Atlantic climate pacemaker for the centuries. Science, 288: 1984-1985. http://dx.doi. org/10.1126/science.288.5473.1984

KRISTIANSEN T., R. G. LOUGH, F. E . WERNER, E. A. BROUGHTON, and L. J. BUCKLEY. 2009. Individualbased modeling of feeding ecology and prey selection of larval cod on Georges Bank. Mar. Ecol. Prog. Ser., 376: 227-243. http://dx.doi.org/10.3354/meps07796

MADIN, L. P., P. KREMER, P. H. WIEBE, J. E. PURCELL, E. H. HORGAN, and D. A. NEMAZIE. 2006. Periodic swarms of the salp Salpa aspera in the slope water off the NE United States: biovolume, vertical migration, grazing, and vertical flux. Deep-Sea Res. I, 53: 804-819. http:// dx.doi.org/10.1016/j.dsr.2005.12.018

MCGILLICUDDY, D. J. JR. and A. BUCKLIN. 2002. Intermingling of two Pseudocalanus species on Georges Bank. J. Mar. Res., 60: 583-604. http://dx.doi. org/10.1357/002224002762324185

MCLAREN, I. A. 1966. Predicting development rate of copepod eggs. Biol. Bull., 131: 457-469. http://dx.doi. org/10.2307/1539985

MILLS, K. E., A. J. PERSHING, C. J. BROWN, Y. CHEN, F.-S. CHIANG, D. S. HOLLAND, S. LEHUTA, J. A. NYE, J. C. SUN, A. C. THOMAS, and R. A. WAHLE. 2013. Fisheries management in a changing climate: Lessons from the 2012 ocean heat wave in the Northwest Atlantic. Oceanography 26(2): 191-195. http://dx.doi.org/10.5670/ oceanog.2013.27

MOUNTAIN, D. G., and J. KANE. 2010. Major changes in the Georges Bank ecosystem, 1980s to the 1990s. Mar. Ecol. Prog. Ser., 398: 81-91. http://dx.doi.org/10.3354/ meps08323

PAFFENHOFER, G. A., L. P. ATKINSON, T. N. LEE, P. G. VERITY, and L. R. BULLUCK III. 1994. Distribution and abundance of thaliaceans and copepods off the southeastern U.S.A. during winter. Cont. Shelf Res., 15: 255-280. http:// dx.doi.org/10.1016/0278-4343(94)E0004-6

PERSHING, A. J., C. H. GREENE, J. W. JOSSI, L. O'BRIEN, J. K. T. BRODZIAK, and B. A. BAILY. 2005. Interdecadal variability in the Gulf of Maine zooplankton community, with potential impacts on fish recruitment. ICES J.
Mar. Sci., 62: 1511-1523. http://dx.doi.org/10.1016/j. icesjms.2005.04.025

PYPER, B. J., and R. M. PETERMAN. 1998. Comparison of methods to account for autocorrelation in correlation analysis of fish data. Can. J. Fish. Aquat. Sci., 55: 21272140. http://dx.doi.org/10.1139/f98-201. http://dx.doi. org/10.1139/f98-104

ROBERT, D., K. LEVESQUE, J. A. GAGNÉ, and L. FORTIER. 2011. Change in prey selectivity during the larval life of Atlantic cod in the southern Gulf of St Lawrence. J. Plankton Res., 33: 195-200. http://dx.doi.org/10.1093/ plankt/fbq095

SHERMAN, K. 1980. MARMAP, a fisheries ecosystem study in the NW Atlantic: fluctuations in the icthyoplankton zooplankton components and their potential for impact on the system. In: Advanced Concepts on Ocean Measurements for Marine Biology. F. P. Diemer, F. J. Vernberg, and D. Z. Mirkes, (eds.) Belle W. Baruch Institute for Marine Biology and Coastal Research, University of South Carolina Press, Columbia, S.C., 9-37.

SHERMAN, K., M. GROSSLEIN, D. MOUNTAIN, D. BUSCH, J. O'REILLY, and R. THEROUX. 1996. The Northeast Shelf Ecosystem: An initial perspective. In: The Northeast Shelf Ecosystem. K. Sherman, N. A. Jaworski, and T. J. Smayda, (eds.) Blackwell Science, Cambridge, MA, 103-126.

SIBUNKA, J.D., and M.J. SILVERMAN. 1984. MARMAP surveys of the continental shelf from Cape Hatteras, North Carolina, to Cape Sable, Nova Scotia (1977-1983). Atlas No. 1. Summary of operations. NOAA Tech. Mem. NMFS-F/NEC-33.

1989. MARMAP surveys of the continental shelf from Cape Hatteras, North Carolina, to Cape Sable, Nova Scotia (1984-1987). Atlas No. 3. Summary of operations. NOAA Tech. Mem. NMFS-F/NEC-68.

STEGERT, C., R. JI, and C. S. DAVIS. 2010. Influence of projected ocean warming on population growth potential in two North Atlantic copepod species. Progr. Oceanogr., 87: 264-276. http://dx.doi.org/10.1016/j.pocean.2010.09.013

TAYLOR, A. H. 1995. North-south shifts of the Gulf Stream and their climate connection with the abundance of zooplankton in the UK and its surrounding seas. ICES J. Mar. Sci., 52: 711-721. http://dx.doi.org/10.1016/1054-3139(95)80084-0

THOMPSON, W. J. and J. W. WALLACE. 1998. The Arctic Oscillation signature in the wintertime geopotential height and temperature fields. Geophys. Res. Lett. 25: 1297-1300. http://dx.doi.org/10.1029/98GL00950

VARGAS, C. V., and L. P. MADIN. 2004. Zooplankton feeding ecology: clearance and ingestion rates of the salps Thalia democratica, Cyclosalpa affinis and Salpa cylindrica on naturally occurring particles in the Mid-Atlantic Bight. J. Plankton Res., 26: 827-833. http://dx.doi.org/10.1093/ plankt/fbh068

WIEBE, P. H., L. P. MADIN, L. R. HAURY, G. R. HARBISON, and L. M. PHILBIN. 1979. Diel vertical migration by Salpa aspera: Potential for large-scale particulate organic matter transport to the deep sea. Mar. Bio., 53: 249-255. http:// dx.doi.org/10.1007/BF00952433 
